New Zealand journal of industrial relations, 1988, 13, 49-62

\title{
Injunctions and compliance orders: an analysis of the Labour Court's powers and decisions
}

\author{
John Hughes* and Gordon Anderson **
}

This paper outlines the provisions of the Labour Relations Act 1987 that relate to the lawfulness of strike action and the remedies available in the case of unlawful strikes. The decisions of the Labour Court to date in relation to those remedies are then discussed, in particular the recent decision of the Full Court in the New Zealand Harbours IUW case.

\section{Introduction}

Since the passing of the Labour Relations Act 1987 the Labour Court has had ample opportunity to experiment with its expanded jurisdiction to deal with strikes through the injunction and compliance order provisions of the Act. It has also managed to generate considerable controversy in relation to this aspect of its jurisdiction and in particular to the granting of ex parte and interlocutory orders. As yet however, there has been insufficient time for a clear pattern to emerge that will allow the policy approach of the Court to its new jurisdiction to be predicted. Most of the cases heard to date, and in particular those that have generated the most controversy, have been heard in circumstances where a considered opinion has had to give way to the exigencies of the moment, although the recent decision of the Full Court in New Zealand Harbours IUW v Auckland Harbour Board has now laid down much more substantial guidelines in the case of ex parte applications.

\section{The scheme of the Labour Relations Act}

The Labour Relations Act 1987 represents a major reform of New Zealand's industrial law and in particular the law governing industrial conflict. Central to the new scheme are the following elements of the Act:

(1) The recognition of a right to strike, albeit a limited one, and the consequent protection of unions from some degree of legal liability for engaging in permitted strikes.

* $\quad$ Faculty of Law, University of Canterbury.

** Commercial Law Group, Victoria University of Wellington 
(2) The removal of statutory penalties for illegal strikes and lockouts and their replacement with civil actions at the initiative of those affected by the action. The remedies available include compliance orders, injunctions and damages.

(3) The transfer of much of the jurisdiction of the High Court, as it relates to the applicability of the economic torts in industrial disputes, to the Labour Court. This is primarily a jurisdictional change rather than one of legal substance. However, when taken together with other extensions of the Court's jurisdiction, it does represent a significant move towards the concept of a specialist labour court having exclusive jurisdiction in the areas of employment and industrial relations. Litigation in respect of individual contracts of employment is probably the most significant area remaining outside the Court's jurisdiction. It also remains true that individual workers have only very limited rights of access to the Court. The Court remains in essence a court in which collective disputes are resolved, with personal grievances being in an ambiguous category.

It is these three elements of the Act that form the basis of this paper and which will be discussed below in more detail.

\section{(1) The "right" to strike}

The Objects section for Part X of the Act states that:

The object of this Part of this Act is to establish that-

(a) The right of workers to strike and the right of an employer to lockout are recognised, subject to constraints.

This statement represents the first positive statement of a legally recognised right to strike in New Zealand. One could however remark on the linking of the right to strike with the right to lockout. Whether these two types of conduct are analogous is a matter of some debate. Some commentators prefer to compare strikes with the exercise of managerial prerogative. The following discussion refers to strikes only, although much of the law would also be applicable to lockouts.

Having stated that there is a right to strike, the Act goes on to set out the constraints that limit this right. These constraints are of two types:

(1) Strikes are categorised as "lawful" and "unlawful", and

(2) In some cases certain pre-conditions must be fulfilled before a strike begins, regardless of its lawfulness. The most important case is strikes in essential industries where the appropriate period of notice must be given.

"Lawful" and "unlawful" strikes

Section 233 of the Act defines a range of circumstances in which a strike will be lawful. It is useful to quote these circumstances in full:

(1) Subject to section 234 (3) of this Act a strike ... shall be lawful if-

(a) It relates to a matter that is the subject of a dispute of interest created with intent to procure an award or agreement in substitution for an award or agreement and the date of the expiry of that award or agreement is not more than 60 days after the date of the expiry of the strike or lockout; or 
(b) It relates to a matter that is the subject of a dispute of interest created with intent to procure an award or agreement to cover workers not currently covered by an award or agreement; or

(c) It relates to a matter that the Labour Court has determined under section 180 of this Act is a new matter; or

(d) It relates to a dispute created with intent to procure a redundancy agreement and-

(i) There is no current redundancy agreement, or award or agreement dealing with compensation for redundancy applying;and

(ii) The only workers involved in the strike are those of the employer to whom the redundancy agreement will apply

Section 234 (3) deems that otherwise lawful strikes become unlawful if the provisions of sections 235 and 236 that relate to giving notice in essential industries are not complied with. Section 233 does however seem to override inconsistent provisions in an award or agreement so that an agreement not to strike where the Act declares such a strike to be lawful will be unenforcable. ${ }^{1}$

Section 234 of the Act defines those strikes that are unlawful These strikes are strikes that concern:

(a) a dispute of rights; or

(b) A personal grievance that can be submitted to a grievance committee or the

Labour Court; or

(c) Demarcation issues; or

(d) Union membership... ; or

(e) Cancellation of a union's registration under this Act.

Section 234 also declares some other strikes unlawful including those mentioned above that occur without proper notice and strikes that contravene section 152 (3) in relation to separate negotiations.

Finally, mention should be made of the special defence in section 237 which provides that a strike "shall not be unlawful under section 234 of this Act" if it is justified on the grounds of safety or health. Strangely the reference is to section 234 and thus it would seem such a strike does not enjoy the protection of section 233 .

\section{The trade union "immunity"}

The right to strike that is stated as existing in section 230 consists of an immunity from legal proceedings in some circumstances. The first is that a compliance order can only be granted if a provision of the Act has not been complied with. A strike that is lawful will of course not be a failure to comply with the Act. The second leg of the immunity is that contained in section 233 (2). This states that a strike that is lawful under section 233 (1) shall not give rise to proceedings founded on the torts set out in section 242 (1). Similarly, an injunction under section 243 cannot be granted if the strike comes within section 233 (1). The limits of this immunity should be made clear, at least in outline. There may still be some debate over the details of the immunity and the situation varies depending if the remedy sought is a through a common law action or for a compliance order. The main points are; 
(1) It seems clear that the dominant provision creating the immunity is section 233 . That is to avoid liability in tort the strike must be one that is expressly declared to be lawful by that section. Strikes that fall between sections 233 and 234 (i.e. those that are not expressly declared to be either lawful or unlawful) may still be subject to an action in tort for an injunction or for damages. A straightforward example of this type of strike would be a political strike. Sympathy or secondary strikes to support a lawful strike are not clearly dealt with in the Act and there would seem to be some room for interpretation as to whether workers not to be covered by an award or agreement can strike to support those who will be covered. Such strikes may not be lawful in all cases.

(2) The immunity is limited to the specific torts set out in section 242 (1). This means that actions based on other torts that may be committed in the course of a strike (e.g. nuisance or trespass) or any yet to be discovered torts are still possible. It should be remembered that intimidation was as recent an invention as 1964 and that bare interference with trade or business occasionally rears its head as a possible tort. Indeed the whole area of tort liability is complex and constantly shifting. The section also does not cover actions not based in tort such as those for breach of contract or for economic duress. The latter in particular has formed the basis of an action against unions in the United Kingdom. ${ }^{2}$ The reasons for limiting the immunity in this way are unclear, as the existence of such potential actions was clearly known before the Act was passed. The failure to set out a clear and total immunity for all lawful strikes seems an unnecessary defect in the Act.

(3) The rules applying to an injunction application could effectively limit the immunity. The "serious issue to be tried" test could mean that if an employer can show that there is such an issue as to whether or not a strike is lawful an injunction should be available under the normal rules. The wording of section 243(3) that an injunction shall not be issued if "the Court is satisfied" that the action comes within section 233(1) would seem to indicate that a positive finding of lawfulness is needed to defeat an injunction application. A strike in breach of an order of the Court also becomes independently unlawful by the provisions of section $234(5)$.

\section{(2) Sanctions for strikes}

Section 230 states that:

(d) Statutory penalties are not imposed for an unlawful strike. .:

(e) The remedy for an unlawful strike. .. may be obtained through a civil action for an injunction or damages or both or through a compliance order

This policy is a logical extension of the principles of the Dunlop Report (1978). It also seems sensible to leave the question of whether to seek sanctions in the hands of those affected by the strike as they are presumably the best judges of their own interests. Statutory sanctions are of course available if an order of the Court is disobeyed as are sanctions for contempt of court. As noted by Boast (1988, p. 35) these penalties can be very harsh. ${ }^{3}$ 


\section{(3) The jurisdiction of the Labour Court}

The Labour Relations Act has expanded the Labour Court's jurisdiction in litigation concerning strikes. The intention of these reforms was to allow the specialist Labour Court to deal with litigation arising from industrial conflict and to limit the possibilities for a conflict of jurisdiction. The new jurisdiction has three aspects, the jurisdiction in relation to torts, the jurisdiction in relation to injunctions and the power to issue compliance orders.

\section{Jurisdiction in relation to torts}

Section 242 of the Act provides that:

Where a strike ... is occuring or has occured and as a result proceedings are issued against any party to the strike ... .and such proceedings are founded on the following torts, namely:

(a) Conspiracy; or

(b) Intimidation; or

(c) Inducement of breach of contract; or

(d) Interference by unlawful means with trade, business, or employment,-

the Labour Court shall have full and exclusive jurisdiction to hear and determine such proceedings.

This provision covers all the torts that are normally relied on in cases concerning strikes but they are by no means the only possibilities available (see above). The possibility of actions in the High Court therefore still arises, although the provisions relating to injunctions, discussed below, make this less likely. This section is not however trouble free. The Labour Court's jurisdiction, for example, only arises where the proceedings are against a "party to the strike", a term that is not defined. Although one writer has suggested that it may not include unions or their officials (Harrison, 1987), the Court's decision in the Air New Zealand case seems to indicate that this is not so.

\section{Injunctions}

The Court's jurisdiction in relation to injunctions is wider than that for actions in tort. Section 243 gives the Labour Court exclusive jurisdiction:

Where a strike. .. occurs or is threatened and proceedings are issued for the grant of an injunction to prevent the strike .... 4

While this section goes beyond the four torts named in section 242 (1), the possibility of an action in the High Court is left open if the injunction has some object other than preventing the strike, such as to prevent or limit picketing, especially by non-strikers. The effect of the section is however to shift the great majority of applications for labour injunctions into the Labour Court. The question that has yet to be answered is whether reading might indicate that the Labour Court can only prevent (a threatened strike ?) but that no other court can stop a strike? 
this move will make any real difference to the situation. Under the new Act, as explained below, the relevant law seems unchanged and consequently any change in practice is likely to be a question of degree in the exercise of the Court's discretion. Given the state of the law on injunctions there seems unlikely to be any radical new approach.

\section{The nature of the tort and injunction jurisdiction}

The jurisdiction of the Labour Court in tort and to grant injunctions depends on the actual or potential existence of a strike or lockout. In the absence of either the High Court will still retain jurisdiction. The recent Fletcher Challange case indicates that the question of jurisdiction is to be decided by the High Court if an action is brought in that Court, and presumably in an application for an injunction an arguable case that the action concerned does not amount to a strike may be sufficent to found jurisdiction.

The Labour Court's jurisdiction under the above provisions must be distinguished from its normal jurisdiction. In particular, the provisions of section 279 (4) and section 303 (1) are of importance. These provisions provide that the Court's "equity and good conscience" jurisdiction, either in relation to reaching a decision or in admitting evidence, does not apply to matters brought under sections 242 and 243. In addition, section 309 allows an appeal to the Court of Appeal by any party to proceedings under section 242, although strangely, not section 243 . Normally, appeals are allowed on a point of law only. These provisions, taken with the powers to which they relate, indicate that there has been a transfer of jurisdiction rather than a new or modified jurisdiction.

\section{Compliance orders}

Section 207 (1) of the Labour Relations Act $1987^{5}$ empowers the Labour Court to issue a compliance order where any person has not complied with (a) Any provision of this Act or of any award or agreement or of any rule of a union;
or

(b) Any order, determination, direction, or requirement made or given under this Act by the Labour Court or the District Court or the Commission or a disputes committee or a grievance committee or the Registrar of Unions...

This much expanded power comes within the Court's normal jurisdiction and in industrial relations terms is a preferred remedy.

\section{Compliance orders: the decisions to date}

The power to order compliance is confined to the specific matters set out in section 207 (1) and the Court has made it clear that that power is not available to seek compliance with conditions of employment "in addition to or otherwise available in that award" 6 . This point can be illustrated by two cases. In the Hancock case, where a strike arose from a provisions of section 207 (1) have been amended to take account of the State Sector Act 1988. See sections 2 and 7 of the Labour Relations Amendment Act 1988.

Hancock and Company Ltd. v. Wellington District Hotel etc. IUW. 
"sour and disruptive atmosphere" rather than from the non-observance or non-compliance with any of the listed matters, a compliance order was refused. By contrast, in the New Zealand Starch Products ${ }^{7}$ case, the orders were based on breaches of section 192 which imposes a positive obligation not to strike. Put simply, without the presence of one of the statutory gateways, the Court lacks jurisdiction. Thus an employer could not successfully apply for a compliance order to enforce a purely contractual right or to enforce a section of the Act which contains no positive obligation with which to order compliance. The orders of the Court have thus been confined to orders to comply with one of the listed matters in section 207 (1). As an example, we might consider Caxton Paper Mills Ltd. v. Northern Woodpulp, Paper and Paper Products IUW. In this case, workers had refused to accept a different occupation where their usual work was not available for them. The Labour Court held that this refusal was in breach of the controversial "right" of employers to "readjust staff and to allocate duties" 8 . Had the matter rested there, it is unlikely that a compliance order could have issued (failing an enforceable decision of a grievance or disputes committee). However, a clause in the relevant collective agreement specifically referred to the duty of worker to accept changes in occupation. Insofar as the proper interpretation of this clause led to a finding in the employer's favour, a compliance order was issued.

It remains to be seen how far the limitation imposed by section 207 (1) will affect the enforcement of the general rights reiterated in the Feltex decision. Few awards expressly preserve the right of "managerial prerogative" as a matter of broad principle and the attempted enforcement by compliance order of such a clause might founder on questions of interpretation. Nevertheless, in practical terms, there seems to be little scope for workers to resist successfully changes to terms and conditions dictated by economic necessity if the ultimate consequence of such a refusal is dismissal. The decisions in this area, buttressed by the Feltex case, suggest that the chances of success in a personal grievance claim are slim once the employer establishes a genuine economic basis for the change.

Inevitably, issues of interpretation will be at the forefront in any procedure based on the enforcement of awards or agreements. In exercising its compliance jurisdiction under the Industrial Relations Act 1973, the Arbitration Court suggested that an order for compliance would be premature where serious matters of interpretation remained to be clarified. ${ }^{9}$ This theme was taken up by the Labour Court in an early statement of principle in Air New Zealand Ltd. v. New Zealand Air Line Pilots Association IUW. In this case, Williamson J. stated that:

If the meaning of the provision of the Act or award or agreement or union rule is in dispute, the correct meaning must first be ascertained before it is possible to say that "any person has not observed or not complied with" that provision. Where the meaning of an award provision is in dispute the primary procedure for ascertaining the correct meaning is the disputes procedure of the award. Once the correct meaning is ascertained, compliance is to be expected and may be ordered. In other words, if the breach of obligation is clear the order to comply may flow, but if the obligation itself is unclear there must first be proceedings to define the obligation...

...Under ss(2) of section 207 it is necessary to prove the obligation, the breach of it and the consequential prejudicial effect. It seems to me that there is a difference between an applicant saying to the Court "enforce the obligation" and another saying 
"enforce my version of the obligation". It may be that, in cases where the obligation is fairly clear, the Court considering an application under section 207 will define the obligation and issue an enforcing order. That course of action seems inappropriate in a case where the obligation is unclear and seriously in dispute.

Thus, in Williamson J's words, "the section 207 procedure is not meant to be a method of evading disputes procedures nor of 'fast tracking' disputes procedures".

Whilst the Court may exercise the power to order compliance of its own motion under section 207 (3) (b) of the Labour Relations Act 1987, most applications are likely to come from one or other of the industrial parties. Section 207 (2) states that

where any person ... alleges that that person has been prejudicially affected by a nonobservance of the kind described in sub-section (1) ... that person may commence proceedings against any person in respect of the non-observance or non-compliance ...

Although the Act does not appear to impose any onus on the plaintiff to establish the allegation to any standard of proof ${ }^{10}$, so far this apparent lacuna - emphasised by the use of the word "alleges" - has not caused the Court any problems. Nor are serious problems likely to arise in this context. As the Court of Appeal noted in a different context in Northern etc. Woodpulp Paper and Related Products IUW v New Zealand Forest Products Ltd the wide powers of the Court to admit and call for evidence under section 303 of the Act "underline that often questions of onus may not be of much importance under the Act". Further, the question must be inextricably linked with the exercise of the Court's discretion. That discretion is unlikely to be exercised in favour of ordering compliance where the Court is not satisfied on the evidence that non-observance or non-compliance of the sort envisaged by section 207 has taken place.

The question of "prejudice" under section 207 (2) is primarily one of fact. The prejudice suffered by employers in the case of strikes or non-compliance with provisions in awards or agreements is obviously economic loss through matters such as loss of working time $^{11}$. Unions will suffer more intangible damage, a factor which has acted to their detriment in the past when courts have considered the "balance of convenience" in awarding interlocutory injunctions. However, as was expected, the Labour Court has shown a deeper appreciation of the labour realities than the common law courts in assessing damage to unions in the context of section 207. Thus unions have established "prejudice" where any employer's resistance to the right of entry clause prevented a union from offering membership to persons who prima facie appeared to be entitled to it. ${ }^{12}$ Budgeting problems that arose from an employer's unilateral decision to pay salary monthly, as opposed fortnightly, have also been held to be sufficient. ${ }^{13}$ More significantly, the Court has recognised bargaining disadvantages as "prejudice" where immeasurable weakening and undermining of the negotiating position of the union would have occurred should the employer have been allowed unilaterally to operate shifts in breach of the provisions of a collective agreement which provided for negotiations on the subject. 14 
Whilst the Labour Court has a discretion under section 207, section 186 (f) of the Act clearly states that the primary remedy for a breach of an award or agreement or any provision of the Act itself is an order for compliance. According to Horn C.J., the discretion will be used "sparingly and rarely" where a clear foundation has been laid under section 207. 15 In the Hancock case, where that clear foundation was not laid, the Court exercised its discretion against granting a compliance order where an order to return to work would have done little or nothing to solve the issues leading to the strike. Similarly, in New Zealand Air Line Pilots Association IUW v. Air New Zealand Ltd. in all the circumstances of the case, the Court held that:

it would not be at the present time fair and just between the parties, nor likely to foster the good relationships which they need to preserve ... if the Court were to impose such an obligation as that which is sought.

It was commonly assumed that the power to order compliance would feature most heavily in the field of industrial action and the cases to date bear out that assumption. There is no general power to issue a compliance order where a strike is lawful, and neither will the Court exercise its discretionary power in that way. ${ }^{16}$ The key question in such cases will be whether the strike "relates to" one of the grounds for lawful strikes set out in section 233 of the Act, and the Court will often be faced with the task of disentangling underlying, but causally minor, reasons for the action concerned, from a true dispute of interest founding a lawful strike. ${ }^{17}$ Where a strike is lawful under section 233 , this will of course prevail over any provision to the contrary in the relevant award or agreement. This applied where an award prohibited strikes over efforts to obtain a redundancy agreement in opposition to section 233 which expressly contemplates such action as lawful in defined circumstances (the Nelson Harbour Board case). On the other hand, where there is a strike over a matter listed in section 234 as being unlawful "a strong prima facie case could always be shown to exist for a compliance order" (the Hancock case).

However, the Court has expressed doubts as to the wisdom of issuing compliance orders based on the apprehension that a party will disobey legislative requirements. In New Zealand Hospital Boards IUE v. New Zealand Hotel etc. Employees IAW, the applicants sought an order requiring the union to comply with the requirements of section 235 of the Labour Relations Act 1987 as to notice of strike action in the essential services. The applicants had received notices which, in the view of the Court, were of doubtful validity. Castle J. dismissed the application, holding that:

any form of compliance order is inappropriate in the circumstances of this case where any question of non-compliance of the strike action notices with the requirements of section 235 of the Act is a thing of the past. As I see it, this Court cannot properly order any party in advance of the event to issue any form of notice which will satisfy the requirements of section 235 .

In some cases, compliance orders have been sought not only against the union but against individual union officers, as for example in the New Zealand Starch Products case, and also against workers as in the Caxton Paper Mills case. When compliance is sought against union officials, it usually relates to a prohibition on the making of recommendations and encouragement or inducement to breach the alleged requirement (see,

in the Hancock case.

Nelson Harbour Board v New Zealand Harbours IUW. see, for example, Feltex Industries Ltd v New Zealand Engineering etc. IUW. 
for example, the Caxton Paper Mills case). In this context, the existence of a genuine question of interpretation may well lead the Court to refuse such an order. In the Air New Zealand case, Williamson J. held that:

In considering whether I should make some form of the first order sought I must have regard to a much wider consideration, namely the right of a union to give advice to its members. As I see it a union has a right, similar to that of a professional advisor, to give professional advice to its members concerning their award. That right to give advice necessarily encompasses a right to give advice which may ultimately prove to be incorrect. It seems to me that a Court is not entitled to order a professional advisor to withdraw or alter advice given in good faith. That would be to interfere with the relationship between professional advisor and client. The Court's power is not to order that the incorrect advice be withdrawn but, in appropriate proceedings, to decide the correct interpretation.

\section{Injunctions: the decisions to date}

Often an application for a compliance order will be linked with an application under section 243 for an injunction. Despite a number of applications for injunctions since the Act came into effect, little in the way of guiding principle has been laid down. This lack of principle arises from a number of sources, prominent amongst them being the plain proscription against awarding injunctions against lawful strikes, contained in section 243 (3). ${ }^{18}$ Other factors contributing to the lack of any firm guidelines are the interlocutory nature of the remedy and pressure of time on the Court. As the Court observed, "the need for urgent decisions is limiting." 19

Although the Court has indicated that it will develop its own approach to its new jurisdiction over injunctions ${ }^{20}$, and it has the power under section 307 of the Labour Relations Act to make its own rules, its decisions to date reflect the familiar approach of the common law courts. Indeed, to an extent this is inevitable since the Court is constrained from exercising its wide "equity and good conscience" jurisdiction and its broad powers to admit evidence in such cases (ss. 279 and 303 respectively).

Whilst the appropriate threshold standard of proof in injunction cases remains somewhat indeterminate in labour cases ${ }^{21}$ the Labour Court has adopted the established test under American Cyanamid Co. v Ethicon Ltd of asking whether the applicant has established a serious and/or arguable case to be tried 22 before moving on to consider the balance of convenience. It has also followed the lead of the High Court in the Tip Top Ice Cream case in holding that an injunction should not be awarded against workers who are not party to the proceedings. ${ }^{23}$

see, for example, Feltex Industries Ltd v New Zealand etc. Engineering etc. IUW. New Zealand Public Service Association Inc v Board of Electricity Corporation of New
Zealand Ltd.

20 New Zealand Refining Co Ltd v Auckland District Boilermakers.

21 see the comments of Thorp J in Tip Top Ice Cream Co.Ltd v Northern Clerical etc. IUW.

22 the Public Service Association case.

$23 \quad$ Feltex Industries Ltd. v. New Zealand Engineering etc. IUW. 
The Labour Court has expressed no settled view on whether the reference to "threatened" strikes in section 243 (1) of the Act enables it to grant a quia timet injunction. 24

\section{Ex parte orders}

Perhaps the most controversial decisions of the Labour Court to date are those of its decisions that it have involved ex parte injunctions ${ }^{25}$ and compliance orders so that the familiar arguments as to the essential fairness of such procedures in the industrial context continue to be raised. At least two cases have illustrated the problems that such orders cause. In the Public Service Association case, the injunction was sought late at night in respect of a strike for which the required notice had been given. The application turned on an alleged variation of that notice in a communiction (which the union claimed was part of discussions to control the impact of the strike) and the claimed effect that the variation was alleged to be likely to cause. Technical affidavits presented to back this claim would for practical reasons almost certainly have to be accepted by the Court. Nevertheless the strike did go ahead with little apparent effect, although the injunction did generate considerable ill-will. In the second case, Auckland Harbour Board v New Zealand Harbours IUW, the Court issued an ex parte compliance order, but a few days later after argument from both parties, the order was discharged after the Court accepted that the initial evidence did not present a wholly accurate picture of the dispute.

The Full Labour Court has now given a considered judgment on both ex parte injunctions and compliance orders in New Zealand Harbours IUW v Auckland Harbour Board which should help resolve some of the problems of this aspect of the Court's expanded jurisdiction. The two major questions that the Court was asked to answer were:

(1) Does the Court have jurisdiction or power to make an order for compliance... without giving notice to the party against whom the order is sought and /or proposed to be made?

(2) Does the Court have jurisdiction or power to grant an injunction .... without giving notice to the party against whom the order is sought and /or made?

In the case of compliance orders the Court held 2-1 (Judge Williamson declining to answer) that the Labour court did not have jurisdiction to make an order ex parte. The Court held that the provisions of the Act governing compliance orders did not allow for a hearing in the absence of notice to the other party because the specific provisions of the Act and the regulations amounted to a code on compliance orders and that therefore any inherent power that the Court may have had to make ex parte orders was excluded. The Court based this finding on two reasons: The first was that regulation 59 of the Labour Relations Regulations 1987 specifies that seven days notice must be given of any hearing and although this period may be shortened by an order of a judge under the urgency provisions of section 296 the regulations make no provision for dispensing with notice. In this respect there is a marked contrast with the High Court rules relating to injunctions. The second reason that was given was the need for a proven breach of the type specified in section 207 before a compliance order can be issued, and the Court was inclined to the opinion that this would require that both parties had been heard, or at least had the opportunity to be heard. 
In the case of injunctions however, the Court was unanimous that it did have the power to make an ex parte order. The Court was of the opinion that its jurisdiction in respect of injunctions was largely a transfer of powers from the High Court rather than a new or modified jurisdiction. Moreover the powers transfered included the the High Court Rules and Rule 239 specifically allowed for ex parte orders regardless of any inherent power to make such orders.

The Court in making its decision commented only briefly and in broad terms on the desirability of making such orders. Horn CJ mentioned that the American Cyanimid tests "may need some adaption to suit the industrial scene." Williamson J addressed some of the arguments that have been raised against ex parte injunctions and while accepting that they had some validity he saw them being relevant, not to jurisdiction, but rather to the exercise of the Court's discretion in making an order. Indeed Willimson J went to some length to explain both the discretionary nature of an ex parte injunction and the availability of procedures to challenge such orders. His comments did not however go as far as the comment he made in respect of compliance orders that "I cannot presently think of any circumstance in which a compliance order should be made ex parte ".

\section{Conclusion}

The Labour Relations Act 1987 has given the Labour Court a much expanded jurisdiction to deal with industrial conflict, an expansion that has been largely at the expense of the High Court. This reform would seem to reinforce the long legislative policy of placing these disputes in the hands of a specialist labour court, although it must be remembered that there has, at the same time, been a significant change in the nature and structure of that Court. The Labour Court, with the removal of its lay members for the majority of its business, is now much closer to the traditional judicial model and especially so in the exercise of its tortious and injunctive jurisdiction where the "equity and good conscience" provisions do not apply. The new provisions regulating strikes, and the limited immunity for liability in respect of strikes, also reflect an increasing legalism in particular in the distinction between interest and rights disputes and the increasing emphasis on the sanctity of agreements and the use of set procedures to resolve disputes.

The basic framework and structure within which the expanded jurisdiction will operate are now reasonably clear, but at the same time it is clear that legal rules and solutions are not always adequate to solve an industrial dispute. The Hancock case provided a simple but effective illustration of this. The success of the new Act is yet to be demonstrated but it is clear that it will be no panacea and that the traditional tensions between the law and industrial practices are likely to continue.

\section{References}

Boast, R (1988) Injunctions and compliance orders: some procedural issues New Zealand journal of industrial relations 13(1): 33-40.

Harrison, R (1987) Labour Relations Act 1987 unpublished paper, New Zealand Law
Society seminar. 


\section{List of cases}

Air New Zealand Ltd. v. New Zealand Air Line Pilots Association IUW, unreported, Labour Court, 22 October 1987, LC 22/87

American Cyanamid Co. v Ethicon Ltd [1975] AC 396

Auckland Harbour Board v. New Zealand Harbours IUW, unreported, Labour Court, 21 October 1987, LC 24A/87

Auckland Harbour Board v. New Zealand Harbours IUW, unreported, Labour Court, 29 October 1987, LC 41/87

Caxton Paper Mills Ltd. v. Northern Woodpulp, Paper and Paper Products IUW, unreported, Labour Court, 10 September 1987, LC 6/87

Feltex Industries Ltd. v. New Zealand Engineering etc. IUW, unreported, Labour Court, 14 December 1987, LC 70/87

Feltex Woven Carpets Ltd. v. New Zealand etc. Woollen Mills etc. IUW, unreported, Labour Court, 28 August 1987, LC 5/87

Fletcher Challange Ltd v New Zealand Labours' etc. IUW, unreported, High Court, 10 March 1988, CP $79 / 88$

Hancock and Company Ltd $\mathrm{v}$ Wellington District Hotel etc. IUW, unreported, Labour Court, 2 October 1987, LC 9/87

Nelson Harbour Board v New Zealand Harbours IUW, unreported, Labour Court, 5 October 1987, LC 8/87

New Zealand Air Line Pilots Association IUW v. Air New Zealand Ltd, unreported, Labour Court, 16 October 1987, LC 30/87

New Zealand Engineering etc. IUW v. Benchmark Jewellery (New Zealand) Ltd, unreported, Labour Court, 23 October 1987, LC 32/87

New Zealand Harbours IUW v Auckland Harbour Board, unreported, Labour Court 7 October 1987, LC 11/87

New Zealand Harbours IUW v Auckland Harbour Board, unreported, Labour Court 21 March 1988, WLC 28/88

New Zealand Hospital Boards IUE v. New Zealand Hotel etc. Employees IAW, unreported, 10 November 1987, LC 37/87

New Zealand Meat Processors etc. IUW v. Fortex Group Ltd., unreported, Labour Court, 20 November 1987 , LC 53/87

New Zealand Public Service Association.Inc. v. Board of Electricity Corporation of New Zealand Ltd., unreported, 4 November 1987, LC 34/87

New Zealand Refining Co. Ltd. v. Auckland District Boilermakers unreported, Labour Court, 20 August 1987, LC 3/87 
New Zealand Shop Employees IUW v Fletcher Merchants Ltd, unreported, Labour Court, 20 May 1987 , AC 56/87

New Zealand Starch Products Ltd $\mathrm{v}$ New Zealand Food Processing etc IUW unreported, Labour Court, 7 August 1987, LC 1/87

Northern Clerical etc. IUW v. Russell and Somers Ltd., unreported, Labour Court, 8 December 1987, LC 66/87

Northern etc. Woodpulp Paper and Related Products IUW v New Zealand Forest Products Ltd [1981] ACJ 613

Tegel Poultry Co. Ltd. v. New Zealand etc. Food Processing etc. IUW, unreported, Labour Court, 19 November 1987, LC 55/87

Tip Top Ice Cream Co. Ltd. v. Northern Clerical etc. IUW (1987) NZELC 78-092

Universe Tankships Inc. of Morovia v ITWF [1983] 1AC 366 